\title{
PENGARUH MODEL PEMBELAJARAN DISCOVERY LEARNING TERHADAP HASIL BELAJAR BIOLOGI MAHASISWA SEMESTER VI UNIMUDA SORONG TAHUN 2019
}

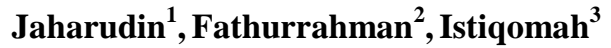 \\ ${ }^{1}$ Program Studi Pendidikan Biologi FKIP UNIMUDA Sorong \\ ${ }^{2}$ Program Studi Ilmu Pengetahuan Alam FKIP UNIMUDA Sorong \\ Universitas Pendidikan Muhammadiyah
}

\author{
jaharudin2008@gmail.com
}

\begin{abstract}
ABSTRAK.
Penelitian ini bertujuan untuk mengetahui pengaruh model pembelajaran discovery learning terhadap hasil belajar mahasiswa mata kuliah ekologi hewan pada submateri keaneragaman komunitas. Jenis penelitian ini adalah eksperimen semu menggunakan kelas kontrol dan eksperimen. Kelas eksperimen menggunakan model pembelajaran discovery learning dan kelas kontrol tanpa model pembelajaran discovery learning. Analisis data berupa uji validitas, $\mathrm{n}$ gaint, dan uji t tidak berpasangan, analisis nilai afektif dan psikomotor, uji mann whitney $U$ dan uji linear sederhana. Hasil penelitian menunjukkan bahwa nilai signifikansi aspek kognitif dan afektif sebesar $p(0,000)<\alpha(0,05)$, sedangkan nilai signifikansi aspek psikomotor sebesar p $(0,029)<\alpha(0,05)$, hal ini berarti bahwa ada pengaruh model pembelajaran discovery learning terhadap hasil belajar. Besaran pengaruh model pembelajaran discovery learning terhadap hasil belajar siswa aspek kognitif sebesar 52,1\%, sedangkan pada aspek afektif dan psikomotor tidak dapat dianalisis secara lanjut besaran pengaruhnya karena berupa data ordinal.
\end{abstract}

Kata Kunci : Model pembelajaran discovery learning, hasil belajar mahasiswa, aspek kognitif, aspek afektif, dan aspek psikomotor.

\begin{abstract}
.
This study aims to determine the effect of discovery learning learning models on student learning outcomes in animal ecology courses in community diversity submersion. This type of research is quasi-experimental using control and treatment classes. The treatment class uses the discovery learning model and the control class without the discovery learning model. Data analysis was in the form of validity test, $n$-gain test, unpaired t test, affective and psychomotor value analysis, mann whitney $U$ test, and simple linear regression. The results showed that the significance value of cognitive and affective aspects was $p(0,000)<\alpha(0.05)$, while the significance value of psychomotor aspects was $p(0.029)<\alpha(0.05)$, this meant that there was an influence on the discovery learning model learning of learning outcomes. The magnitude of the effect of discovery learning models on cognitive aspects of student learning outcomes by 52.1\%, while the affective and psychomotor aspects can not be further analyzed the amount of influence because it is in the form of ordinal data.
\end{abstract}

Keywords: Discovery learning learning model, student learning outcomes, cognitive aspects, affective aspects, and psychomotor aspects.

\section{Pendahuluan}

Pendidikan mempunyai arti yang sangat penting dalam kehidupan kita, baik dalam kehidupan individu, bangsa maupun negara. Oleh karena itu pendidikan harus dilaksanakan dengan sebaikbaiknya, sehingga sesuai dengan tujuan. Keberhasilan suatu bangsa terletak pada mutu pendidikan yang dapat meningkatkan kualtias sumber daya manusianya.

Pendidikan Tinggi dihadapkan pada problematika era globalisasi yang kompleks, mahasiswa dituntut harus memenuhi tujuan dan sasaran pencapaian pembelajaran sesuai dengan kompetensi bidang yang dipelajari.mahasiswa dapat mengaplikasikan pengetahuan keilmuwan yang dipelajari dalam kehidupan sehari-hari sesuai dengan kompetensi yang dibutuhkan oleh pasar kerja. Kondisi realitas dilapangan saat ini dengan ketersediaan sumber belajar yang sudah tidak terbatas diera digital, mahasiswa dapat mengakses sumber- sumber belajar yang digunakan dalam pembelajaran sepeti; sumber internet website, jurnal, e-books dan sumber belajar lainnya. Hal ini menunjukkan bahwa proses pendidikan yang dilaksanakan pada setiap jenjang harus berbasis pada keaktifan dan memicu rasa ingin tahu, mengangkat permasalahan untuk mengonstruksi pengetahuan, atau berbasis proyek untuk membangun pengetahuan mahasiswa. Proses pembelajaran tentunya dilaksanakan untuk mencapai tujuan pembelajaran nasional. Ketercapaian tujuan pembelajaran ditentukan oleh kompenen-komponen yang berperan dalam pembelajaran, yaitu dosen, 
mahasiswa, serta strategi, metode, dan model pembelajaran yang digunakan.

Model pembelajaran bertujuan untuk mempermudah proses pembelajaran dan mendukung tercapainya suatu tujuan pembelajaran. Pembelajaran akan lebih bermakna apabila mahasiswa berpartisipasi aktif dalam kegiatan pembelajaran dikampus. Model pembelajaran discovery learning merupakan proses pembelajaran yang meniti beratkan pada kemampuan mahasiswa dalam memecahkan suatu persoalan atau permasalahan dalam proses pembelajaran melalui rasa ingin tahunya dalam menemukan hal penting pada materi pembelajaran (Ilahi, 2012). Dalam proses pembelajaran, guru atau dosen tidak menyajikan bahan ajar dalam bentuk final, akan tetapi mahasisava diberi peluang untuk mencari dan menemukan sendiri informasi-informasi yang berkaitan dengan materi untuk memecahkan suatu permasalahan dalam materi pembelajaran (Djamarah, 1996).

Materi Ekologi Hewan sangat berkaitan langsung dengan kehidupan nyata, kita dapat mengamati secara langsung salah satu submateri Keaneragaman Komunitas pada sintak generalization dapat menggunakan ruang terbuka hijau berdasarkan habitat hewan yang berada disekitar komplek Kampus Universitas Pendidikan Muhammadiyah (UNIMUDA) Sorong.

\section{Metode Penelitian}

Penelitian ini merupakan penelitian eksperimen semu (Quasy Experiment). Penelitian jenis eksperimen semu menggunakan 2 kelas penelitian, yaitu kelas perlakuan atau experiment dengan menggunakan model pembelajaran discovery learning yang dipilih secara purposive sampling, dan kelas kontrol tanpa menggunakan model pembelajaran discovery learning. Kelas sampel dipilih dengan pertimbangan nilai hasil belajar mahasiswa pada mata kuliah ekologi hewan, yangberjumlah46orang.

Penyelidikan yang dilakukan yaitu mengidentifikasi komponen organisme hewan yang ada di lingkungan kampus Unimuda Sorong. Kemudian dilanjutkan menghitung spesies hewan yang ada di lingkungan kampus sebagai hubungan antar komponen ekosistem. Kelas kontrol diajarkan tanpa model pembelajaran discovery learning. Instrumen penelitian aspek kognitif berupa soal pilihan ganda dan esai. Instrumen penelitian aspek afektif berupa lembar penilaian sikap beserta rubik. Sedangkan Instrumen penelitian aspek psikomotorik berupa lembar penilaian presentasi mahasiswa.

Data penelitian ini berupa data kuantitatif hasil belajar mahasiswa. Data aspek kognitif mahasiswa dianalisis menggunakan uji n-gain. Uji ini digunakan untuk menormalisasi daba penelitian yang didapat. Menurut Meltser (2002), data yang normal atau tidak normal berpengaruh pada penggunaan analisa data lanjutan serta menentukan arah signifikan (positif atau negatif). Nilai n-gain dari aspek kognitif ini digunakan untuk uji $\mathrm{t}$ independen. Kemudian nilai n-gain tersebut diuji lanjut menggunakan regresi linear sederhana. Sedangkan data aspek afektif dan psikomotor dianalisis menggunakan uji mann whitney U. Menurut Meltser (2002), rumusan nilai n-gain sebagai berikut.

$$
\mathbf{g}=\frac{\text { nila: postes - nila: pretes }}{\text { nilai maksimum - nilai pretes }}
$$

\section{Pembahasan \\ Aspek kognitif}

Nilai pretes dan postes masing-masing kelas digunakan sebagai data uji n-gain. Uji n- gain digunakan untuk megetahui kategori kenaikan nilai mahamahamahasiswa. Nilai n-gain ini juga digunakan sebagai data uji lanjutan. Nilai n-gain pada kelas penelitian disajikan pada Gambar 1 berikut.

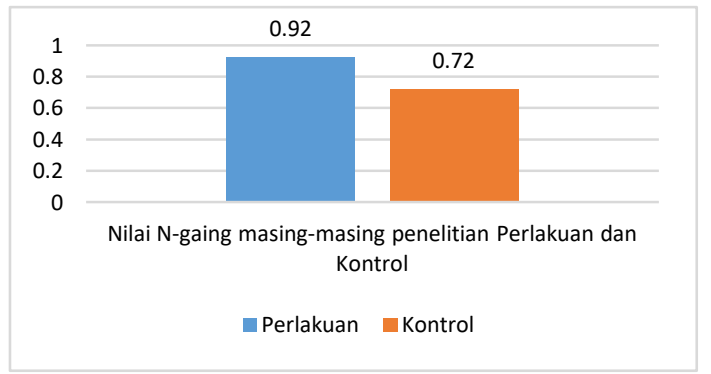

Gambar 3. 1. Nilai N-gain pada Masing-masing Kelas Penelitian

Berdasarkan Gambar 3.1 diketahui bahwa nilai n-gain kelas perlakuan sebesar 0,92 , sedangkan nilain $\mathrm{n}$-gain pada kelas kontrol sebesar 0,72 . Nilai n-gain masing- masing kelas penelitian ini digunakan untuk pengujian $t$ independen. Berdasarkan hasil pengujian $t$ independen diketahui bahwa $\mathrm{p}(0,000)<\alpha(0,05)$. Hal ini menunjukkan bahwa ada pengaruh model pembelajaran discovery learning terhadap hasil belajar mahasiswa Biologi FKIP Unimuda Sorong.

Kemudian nilai n-gain tersebut diuji lanjut menggunakan uji regresi linear sederhana. Berdasarkan hasil pengujian regresi linear sederhana diketahui bahwa besar pengaruh model pembelajaran discovery learning terhadap hasil belajar mahasiswa aspek kognitif, yaitu sebesar $52,1 \%$. Sedangkan nilai koefisien korelasi sebesar 0,72 , berarti ada korelasi yang kuat antara model pembelajaran discovery learning terhadap hasil belajar mahasiswa aspek kognitif.

\section{Aspek Afektif}

Data afektif mahasiswa digunakan dalam pengujian rata-rata nilai afektif dan uji mann 
whitney U. Nilai rata-rata aspek afektif disajikan pada Gambar 3.2. berikut.

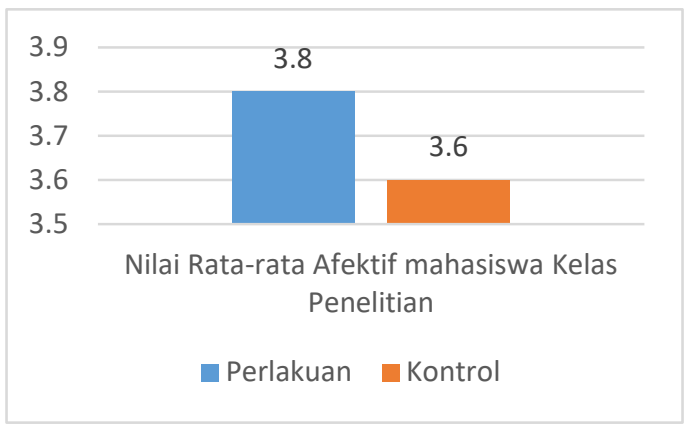

Gambar 3.2 Nilai Rata-rata Afektif mahasiswa Kelas

$$
\text { Penelitian }
$$

Berdasarkan Gambar 3.2 nilai rata- rata afektif diketahui bahwa nilai rata-rata afektif kelas perlakuan sebesar 3,80. Sedangkan nilai rata-rata afektif kelas kontrol sebesar 3,60. Nilai afektif kedua kelas penelitian berkategori sangat baik. Nilai afektif ini digunakan untuk uji mann whitney U. Berdasarkan hasil pengujian mann whitney u diketahui bahwa nilai $\mathrm{p}(0,000)<\alpha$ $(0,05)$. Hal ini berarti bahwa ada pengaruh model pembelajaran discovery learning terhadap hasil belajar mahasiswa. Besaran pengaruh model pembelajaran discovery learning terhadap hasil belajar aspek afektif tidak dapat dihitung karena berupa data ordinal.

\section{Aspek Psikomotor}

Data psikomotor mahasiswa digunakan dalam pengujian rata-rata nilai psikomotor dan uji mann whitney U. Nilai rata-rata aspek psikomotor disajikan pada Gambar 3.3 berikut.

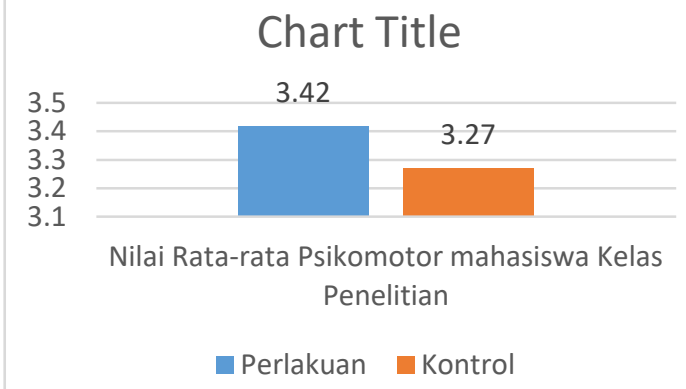

Gambar 3.3 Nilai Rata-rata Psikomotor mahasiswa Kelas

\section{Penelitian}

Berdasarkan Gambar 3.3 nilai rata-rata psikomotor diketahui bahwa nilai rata-rata psikomotor kelas perlakuan sebesar 3,42. Sedangkan nilai rata-rata psikomotor kelas kontrol sebesar 3,27. Nilai psikomotor kedua kelas penelitian berkategori baik. Nilai psikomotor ini digunakan untuk uji mann whitney U. Berdasarkan hasil pengujian mann whitney $\mathrm{u}$ diketahui bahwa nilai $\mathrm{p}(0,029)<\alpha(0,05)$. Hal ini berarti bahwa ada pengaruh model pembelajaran discovery learning terhadap hasil belajar mahasiswa mata kuliah ekologi hewan. Besaran pengaruh model pembelajaran discovery learning terhadap hasil belajar aspek psikomotor tidak dapat dihitung karena berupa data ordinal.

Aspek kognitif

Kemudian nilai n-gain tersebut diuji lanjut menggunakan uji regresi linear sederhana. Berdasarkan hasil pengujian regresi linear sederhana diketahui bahwa besar pengaruh model pembelajaran discovery learning terhadap hasil belajar mahasiswa aspek kognitif, yaitu sebesar 52,1\%. Sedangkan nilai koefisien korelasi sebesar 0,72 , berarti ada korelasi yang kuat antara model pembelajaran discovery learning terhadap hasil belajar mahasiswa aspek kognitif.

Model pembelajaran discovery learning berpengaruh terhadap hasil belajar mahasiswa aspek kognitif ini karena membaurkan 5 kegiatan sekaligus berupa mengumpulkan literatur penunjang materi, diskusi, pengamatan langsung, presentasi, dan evaluasi mata kuliah ekologi hewan pada sumateri keaneragaman komunitas. Kegiatan mengumpulkan literatur penunjang materi terjadi pada sintak data collection. Mereka mengumpulkan materi penunjang mengenai komponen ekosistem dan hubungan antar komponen ekosistem dari berbagai buku pelajaran Biologi dan searching di google. Tahapan ini, kognitif mahasiswa yang dikembangkan berada pada ranah C1-C5.

Proses pengamatan langsung ke lingkungan ini berpengaruh pada daya ingat mahasiswa. Menurut Kawuryan \& Raharjo (2012) dan Pearce (2013), daya ingat manusia dipengaruhi oleh panca indera, terutama mata (Penglihatan). Mata dapat dengan cepat merekam semua kegiatan dan objek-objek yang ada disekeliling manusia, kemudian dialihkan ke otak melalui serabut-serabut nervus optik. Rekaman ini diubah menjadi kode-kode yang dapat dibaca dan disimpan oleh otak. Kode-kode tersebut disimpan dalam memori jangka panjang di otak, sehingga menjadi sebuah pengalaman yang sulit untuk dilupakan. Selain itu, pengamatan yang dilakukan ini membuat mahasiswa dapat berperan aktif dalam proses pembelajaran sehingga mahasiswa merasa antusias dan tidak bosan dalam belajar.

Selanjutnya pada tahap generalization, mahasiswa mempresentasikan hasil pengamatannya. Tahap ini mahasiswa dapat mengungkapkan pengetahuannya tentang komponen-komponen keaneragaman komunitas hewan beserta hubungan antar komponen dari 
hasil studi literatur dan fakta langsung di lingkungan kampus mereka. Mahasiswa melakukan pertukaran hasil penelitian dan pengetahuan dalam forum presentasi ini. Selain itu, pada tahapan ini juga dilakukan evaluasi materi menggunakan data penelitian yang dilakukan sebelumnya. Penyampaian materi ini bertujuan untuk memverifikasi ulang konsep yang didapat mahasiswa sehingga pengetahuan mahasiswa menjadi lebih luas mengenai keaneragamkan komunitas hewan dalam beriteraksi sesame komponen-komponen lainnya.

Aspek afektif

Nilai rata- rata afektif diketahui bahwa nilai rata-rata afektif kelas perlakuan sebesar 3,80. Sedangkan nilai rata-rata afektif kelas kontrol sebesar 3,60. Nilai afektif kedua kelas penelitian berkategori sangat baik. Nilai afektif ini digunakan untuk uji mann whitney U. Berdasarkan hasil pengujian mann whitney u diketahui bahwa nilai $\mathrm{p}$ $(0,000)<\alpha(0,05)$. Hal ini berarti bahwa ada pengaruh model pembelajaran discovery learning terhadap hasil belajar mahasiswa.

Model pembelajaran discovery learning berpengaruh terhadap hasil belajar mahasiswa ini karena sintak data collection, data processing dan verification dapat membentuk sikap mahasiswa. Aspek afektif yang dicapai pada penelitian ini adalah ranah A3, yaitu penilaian dan penentuan sikap. Mahasiswa mampu memikirkan sikap yang baik ataupun buruk untuk dilakukan oleh dirinya maupun orang lain.

Materi yang didapat mahasiswa dari pengumpulan data dan diskusi membentuk sikap jujur mahasiswa dalam melakukan praktikur. maupun menjawab rumusan masalah yang telah ditentukan, sehingga terbentuk juga sikap disiplin mahasiswa. Selain itu, tahap pengumpulan data dan diskusi dapat menumbuhkan rasa ingin tahu mahasiswa yang lebih besar mengenai komponen ekosistem beserta hubungan antar komponen ekositem di lingkungan kampus. Kegiatan praktikum pada tahap verification menekankan mahasiswa untuk memiliki rasa bertanggung jawab dalam ketepatan penggunaan alat praktikum yang berkaitan juga dengan data hasil praktikum. Menurut Supriyanto (20154), pengamatan langsung pada tahap verificat6on dapat menumbuhkan rasa antusias mahasiswa untuk belajar sehingga berdampak positif pada sikap afektif mahasiswa. Oleh karena itu, model pembelajaran discovery learning dapat mempengaruhi hasil belajar mahasiswa aspek afektif.

\section{Aspek psikomotor}

Nilai rata-rata psikomotor diketahui bahwa nilai rata-rata psikomotor kelas perlakuan sebesar 3,42. Sedangkan nilai rata-rata psikomotor kelas kontrol sebesar 3,27. Nilai psikomotor kedua kelas penelitian berkategori baik. Nilai psikomotor ini digunakan untuk uji mann whitney U. Berdasarkan hasil pengujian mann whitney u diketahui bahwa nilai p $(0,029)<$ $\alpha(0,05)$. Hal ini berarti bahwa ada pengaruh model pembelajaran discovery learning terhadap hasil belajar mahasiswa mata kuliah ekologi hewan.

Model pembelajaran discovery learning berpengaruh terhadap hasil belajar mahasiswa aspek psikomotor karena dapat menumbuhkan sikap percaya diri mahasiswa dalam mengeksplor keterampilan dirinya. Konsep yang mahasiswa dapat dari tahap data collection, data processing dan verification membuat mahasiswa yakin terhadap hasil analisis yang mereka presentasikan sehingga mereka mampu mengolah forum diskusi dengan baik. Kegiatan presentasi hasil analisis ini menekankan pada aspek psikomotor mahasiswa tingkat, yaitu gerakan yang terbiasa. Aspek psikomotor mahasiswa selaras dengan aspek kognitif mahasiswa.

Menurut Pidarta (2009), orang yang berdaya kreatif tinggi, juga memiliki intelligence quotient (IQ) yang tinggi. Daya kreatif menekankan pada kemampuan dalam menciptakan gagasan baru untuk memberikan solusi dari sebuah permasalahan. Mahasiswa yang terampil dapat dengan cepat menganalisis teori, konsep dan fakta-fakta yang ada untuk solusi permasalahan tersebut. Oleh karena itu, aspek psikomotor sejalan dengan aspek kognitif dan afektif mahasiswa.

\section{Kesimpulan}

Model pembelajaran discovery learning berpengaruh terhadap hasil belajar mahasiswa mata kuliah ekologi hewan yang ditunjukkan dengan nilai signifikansi aspek kognitif dan afektif sebesar p $(0,000)<\alpha(0,05)$, serta nilai signifikansi aspek psikomotor sebesar p $(0,029)<$ $\alpha(0,05)$. Besaran pengaruh model pembelajaran discovery learning terhadap hasil belajar aspek kognitif sebesar $52,1 \%$, sedangkan pada aspek afektif dan psikomotor tidak dapat dianalisis besaran pengaruhnya karena data ordinal.

\section{Daftar pustaka}

Cahyani Tri, Marina Rizki, Dwi Astuti, Sri \& Mariadi. 2015. Pengaruh Pembelajaran

Discovery Learning terhadap Kemampuan Berpikir Logis Siswa Kelas X MIA Muhammadiyah 1 Surakarta Tahun Pelajaran 2013/2014. Jurnal Pendidikan Biologi 7 (1): 113-119.

Djamarah, S. B Dan Aswan . Z. 2010. Strategi Belajar Mengajar. Jakarta: Rineka Cipta

Dina, Arifatud, Mawarsih, Dian Venissa \& 
Suprapto, Rohmat. 2015. Implementasi

Kurikulum 2013 pada Perangkat Pembelajaran

Model Discovery Learning Pendekatan

Scientific terhadap Kemampuan Matematis

Materi Geometri SMK. Jurnal JKPM 2 (1): 22-31.

Idi, Abdullah. 2014. Pengembangan Kurikulum. Jakarta: Gramedia.

Ilahi MT. 2012. Pembelajaran Discovery Strategy dan Mental Vocational Skill.

Yogyakarta: DIVA Press.

Kawuryan, Fajar \& Raharjo, Trubus. 2012. Pengaruh Stimulasi Visual untuk

Meningkatkan Kemampuan Membaca pada Anak Disleksia. Jurnal Psikologi Pitutur 1 (1): 9-20.

Meltser, E. David. 2002. The Relationship between Mathematics Preparation and Conceptual Learning Gains in Physics: A Possible "Hidden Variable" in Diagnostic Pretest Scores. Am. J. Phys 70 (12): 1259-1268.

Pearce, C. Evelyn. 2013. Anatomi dan Fisiologi untuk Paramedis. Jakarta: PT. Gramedia Pustaka Utama.

Pidarta, Made. 2009. Landasan Kependidikan. Jakarta: Rineka Cipta.

Reece, Urry, Wasserman, Minorsky, \& Jackson. 2005. Campbell Biology 9th ed. America: Benjamin Cummings.

Sulistyo, Edy \& Mubarok, Chusni. 2014. Penerapan Model Pembelajaran Discovery Learning terhadap Hasil Belajar Siswa Kelas X TAV pada Standar Kompetensi Melakukan Instalasi Sound System di SMK Negeri 2 Surabaya. Jurnal Pendidikan Teknik Elektro 3 (1): 215-221.

Sunarti \& Rahmawati, Selly. 2014. Penilaian dalam Kurikulum 2013. Yogyakarta: Penerbit Andi.

Supriyanto, Bambang. 2014. Penerapan Discovery Learning untuk Meningkatkan Hasil Belajar Siswa Kelas VI B Mata Pelajaran Matematika Pokok Bahasan Keliling dan Luas Lingkaran di SD N Tanggul Wetan 02 Kecamatan Tanggul Kabupaten Jember. Jurnal Pancaran 3 (2):65-74.

Wahjudi, Eko. 2014. Penerapan Discovery Learning dalam Pembelajaran IPA Sebagai Upaya untuk Meningkatkan Hasil Belajar Siswa Kelas IX-1 di SMP Negeri 1 Kalianget. Jurnal Lensa 5 (1): 1-15. 